\title{
MANAJEMEN PERPUSTAKAAN SEKOLAH DALAM MEREALISASIKAN PENGEMBANGAN KURIKULUM 2013 (KURTILAS) DI SMK WIRADIKARYA CISEENG BOGOR
}

\author{
Arief Rachman Badrudin ${ }^{1}$ \\ ${ }^{1}$ Dosen Teteap Prodi Manajemen Pendidikan Islam STAI Al Hidayah Bogor \\ ariefbadrudin@gmail.com
}

Received: 21/01/2019, Accepted: 23/01/2019, Published: 28/01/2019

\begin{abstract}
This study aims to determine the management of school libraries in supporting the implementation of the 2013 Curriculum (Kurtilas) and find out the obstacles in realizing the Kurtilas at Ciseeng Wiradikarya Vocational School, Bogor Regency. This study uses a qualitative approach. Data collection techniques were obtained through observation, interviews, and documentation studies. School libraries held at the school level function to support the achievement of the objectives of the learning process and foster interest in reading students so that awareness grows to be able to learn independently. The 2013 curriculum is an operational curriculum compiled and implemented by each education unit. The implementation and development of Kurtilas really needs important sources of information in the learning process for students, especially libraries. The results of the study suggest that library management at Ciseeng Bogor Wiradikarya Vocational School is quite supportive in realizing the 2013 Curriculum (Kurtilas) especially in achieving learning objectives in schools, but library management is now prioritized in providing collections of library materials, provision and arrangement of visitor reading rooms and there is a good arrangement of book collections and the presence of librarians who are experts in their fields. The constraints faced by Wiradikarya's SMK library in supporting the realization of the 2013 curriculum include; human resources, facilities and infrastructure and limited funds.
\end{abstract}

Keywords: management, library, curriculum 2013

\begin{abstract}
ABSTRAK
Penelitian ini bertujuan untuk mengetahui pengelolaan perpustakaan sekolah dalam mendukung implementasi Kurikulum 2013 (Kurtilas) dan mengetahui kendala-kendalanya dalam merealisasikan Kurtilas tersebut di SMK Wiradikarya Ciseeng Kabupaten Bogor. Penelitian ini menggunakan pendekatan kualitatif. Teknik pengumpulan data diperoleh melalui observasi, wawancara, dan studi dokumentasi. Perpustakaan
\end{abstract}


sekolah yang diselenggarakan di tingkat sekolah berfungsi untuk mendukung tercapainya tujuan dari proses pembelajaran dan menumbuhkan minat baca peserta didik sehingga tumbuh kesadaran untuk dapat belajar mandiri. Kurikulum 2013 merupakan kurikulum operasional yang disusun dan dilaksanakan oleh masing-masing satuan pendidikan. Implementasi dan pengembangan Kurtilas sangat membutuhkan sumber-sumber informasi penting dalam proses pembelajaran bagi peserta didik terutama perpustakaan. Hasil penelitian menyimpulkan, bahwa pengelolaan perpustakaan di SMK Wiradikarya Ciseeng Bogor cukup mendukung dalam merealisasikan Kurikulum 2013 (Kurtilas) terutama dalam mencapai tujuan pembelajaran di sekolah, namun pengelolaan sarana perpustakaan saat ini lebih diprioritaskan pada penyediaan koleksi bahan pustaka, penyediaan dan penataan ruang baca pengunjung dan adanya penataan koleksi buku dengan baik serta adanya tenaga pustakawan yang ahli dalam bidangnya. Adapun kendala yang dihadapi perpustakaan SMK Wiradikarya dalam mendukung realisasi Kurikulum 2013 di antaranya; sumber daya manusia, sarana, dan prasarana serta keterbatasan dana.

\section{A. PENDAHULUAN}

Masyarakat global seperti dewasa ini adalah masyarakat terbuka, rasional, dan kritis. Sudah tentu, caracara belajar yang indoktriner dan menghafal sudah kurang cocok. Hal yang perlu dikuasai oleh peserta didik adalah informasi yang telah diolah sendiri atau belajar mandiri (digested information). Dengan sendirinya caracara belajar dengan menghafal diluar kepala sudah tidak pada tempatnya lagi, termasuk cara belajar "lecturing". Belajar mandiri atau independent learning harus dapat menggantikan cara belajar menghafal secara rote learning. Tentunya proses belajarmengajar ini harus didukung oleh fasilitas belajar dan sumber-sumber belajar yang memadai, seperti; perpustakaan yang lengkap, laboratorium, dan bengkel-bengkel kerja (M. Hidayat Ginanjar, 2012: 111).

Dalam meningkatkan mutu pendidikan di Indonesia dewasa ini, berbagai upaya telah dilakukan. Salah satunya menyediakan sarana dan prasarana yang dapat menunjang tercapainya tujuan pendidikan, karena pendidikan merupakan suatu proses yang berlangsung secara terus menerus. Melalui kegiatan ini diharapkan dapat dihasilkan insan yang memiliki kepribadian dan kualitas. Pada sisi lain, kegiatan pendidikan merupakan proses yang 
berlangsung dengan sistem yang disesuaikan dengan tujuan pendidikan itu sendiri. Oleh karena itu, untuk menciptakan kualitas sumber daya manusia perlu dikembangkan dan difungsikan sebagaimana mestinya. Tersedianya perpustakaan sekolah memudahkan siswa untuk aktif mengunjungi perpustakaan yang berada di lingkungan sekolah. Perpustakaan menjadi mudah untuk dijangkau oleh siswa maupun guru dengan tujuan pencapaian kurikulum. Perpustakaan sekolah tidak hanya menyediakan buku referensi dan sumber-sumber belajar lainnya, sehingga siswa dapat meningkatkan pengetahuan serta memperluas wawasannya melalui pendayagunaan perpustakaan sekolah tersebut khususnya dalam meningkatkan cara belajar siswa aktif.

$\begin{array}{clr}\text { Sarana } & \text { dan } & \text { prasarana } \\ \text { perpustakaan } & \text { sekolah } & \text { sebagai }\end{array}$
penunjang pelaksanaan pendidikan di sekolah sangat penting, sebab dengan sarana dan prasarana yang telah disediakan oleh lembaga pendidikan, sebagai bagian dari program pendidikan nasional, standar maksimal dalam pengembangan wawasan intelektual sebagai syarat pembangunan dapat dicapai. Pendidikan nasional melibatkan perpustakaan sebagai sarana yang sangat efektif dalam setiap lembaga pendidikan, sebagaimana yang disebutkan dalam Undang-undang Nomor 43 Tahun 2007 Pasal 39 Ayat 1 dan 2, yaitu “(1) setiap penyelenggaraan perpustakaan menyediakan sarana dan prasarana sesuai dengan standar nasional perpustakaan, (2) sarana dan prasarana sebagaimana dimaksud pada Ayat 1 dimanfaatkan dan dikembangkan sesuai dengan kemajuan teknologi informasi dan komunikasi". Dalam sistem pendidikan nasional secara tegas dinyatakan bahwa fungsi pendidikan nasional adalah mengembangkan kemampuan serta meningkatkan mutu kehidupan dan martabat manusia Indonesia dalam rangka upaya mewujudkan tujuan pendidikan nasional. Lebih jauh lagi bahwa fungsi pendidikan nasional untuk memerangi segala kekurangan, keterbelakangan, kebodohan, dan memantapkan ketahanan nasional serta meningkatkan rasa persatuan dan kesatuan berdasarkan kebudayaan bangsa dan kebhineka Tunggal Ikaan (Atmodiwirio, 2008: 29).

Sebagai salah satu sarana pendidikan penunjang kegiatan belajar peserta didik, perpustakaan sekolah memegang peranan yang sangat 
penting dalam memacu tercapainya tujuan pendidikan di sekolah. Sebagaimana disebutkan dalam Undang-undang Sistem Pendidikan Nasional, yaitu Undang-Undang No. 20 Tahun 2003, bahwa setiap satuan pendidikan formal dan non formal menyediakan sarana dan prasarana yang memenuhi keperluan pedidikan sesuai dengan pertumbuhan dan perkembangan potensi fisik, kecerdasan intelektual, sosial, emosional, dan kejiwaan peserta didik.

Lebih lanjut dalam penjelasan Undang-undang Sistem Pendidikan Nasional Pasal 35 disebutkan; "Standar sarana dan prasarana pendidikan mencakup ruang belajar, tempat berolahraga, tempat ibadah, perpustakaan, laboratorium, bengkel kerja, tempat bermain, tempat berkreasi dan berekreasi, dan sumber belajar lain yang diperlukan untuk menunjang proses pem belajaran, termasuk penggunaan teknologi informasi dan komunikasi." (UndangUndang Republik Indonesia No. 20 Tahun 2003).

Berdasarkan hasil observasi dan keterangan dari informan, saat ini, perpustakaan SMK Wiradikarya Ciseeng Kabupaten Bogor menempati ruang praktik, belum memiliki SDM yang sesuai bidangnya, namun ada satu staf yang ditugaskan untuk mengelola perpustakaan. Dalam menjalankan tugas dan fungsinya, staf perpustakaan ini melayani peminjaman dan pengembalian koleksi, baik kepada guru terlebih kepada siswa yang membutuhkan koleksi perpustakaan. Namun, tampaknya masih terdapat beberapa kekurangan, misalnya masih kurangya sarana dan prasarana yang dimiliki, belum seimbangnya antara jumlah koleksi dengan banyaknya siswa yang hal ini tentunya akan berpengaruh pada peningkatan mutu pendidikan di sekolah tersebut khususnya dalam mendukung implementasi Kurikulum 2013.

Berdasarkan kurtilas uraian latar belakang yang dikemukakan di atas, maka pertanyaan mendasar dalam penelitian ini yaitu; bagaimana pegelolaan perpustakaan sekolah dalam mendukung implementasi Kurikulum Tingkat Satuan Pendidikan (KTSP) di SMK Wiradikarya Ciseeng Kabupaten Bogor dan kendala apa saja yang dihadapi perpustakaan dalam mendukung implementasi KTSP di SMK Wiradikarya Ciseeng Kabupaten Bogor? 


\section{B. TINJAUAN TEORITIS}

1. Pengelolaan

Sekolah

Perpustakaan bukan merupakan hal yang baru di kalangan masyarakat, di mana-mana telah diselenggarakan perpustakaan, seperti di sekolah, baik sekolah umum maupun sekolah kejuruan, baik sekolah dasar maupun sekolah menengah atas atau madrasah aliyah. Begitu pula di kantor-kantor, bahkan sekarang telah digalakkan perpustakaanperpustakaan umum baik di tingkat kota maupun kabupaten sampai di tingkat desa.

Secara definitif, perpustakaan sekolah adalah perpustakaan yang berada pada lembaga pendidikan sekolah, yang merupakan bagian integral dari sekolah yang bersangkutan dan merupakan sumber belajar untuk mendukung tercapainya tujuan pendidikan sekolah yang bersangkutan (Hartono, 2016: 26). Keberadaan perpustakaan sekolah bukan hanya sebatas untuk mengumpulkan dan menyimpan bahan-bahan pustaka, melainkan juga untuk membantu para siswa dalam mendapatkan bahan-bahan pelajaran yang diinginkan. Sementara bagi guru, perpustakaan menjadi sumber referensi utama untuk memperoleh matari-materi pelajaran (Hartono, 2016 :28).

Perpustakaan sekolah adalah perpustakaan yang tergabung pada sebuah sekolah, dikelola sepenuhnya oleh sekolah, dan tujuan utama membantu sekolah untuk mencapai tujuan khusus dan tujuan pendidikan pada umumnya (Karmidi Martoatmojo, 2009: 1-2). Adapun tujuan khusus perpustakaan sekolah ialah membantu sekolah mencapai tujuannya sesuai dengan kebijakan sekolah tempat perpustakaan tersebut bernaung (Andi Prastowo, 2012: 73). Perlunya tujuan khusus sekolah karena walaupun sama dalam tujuan umumnya, namun sekolah swasta mempunyai tujuan khusus yang sering berbeda daripada sekolah negeri.

Dengan demikian, perpustakaan sekolah adalah kumpulan bahan pustaka, baik berupa buku-buku maupun bukan buku (non book material) yang diorganisasikan secara sistematis dalam suatu ruang sehingga dapat membantu muridmurid dan guru-guru dalam proses pembelajaran di sekolah.

\section{Tujuan dan Manfaat}

\section{Perpustakaan Sekolah}

Perpustakaan sekolah bertujuan menyerap dan menghimpun informasi 
mewujudkan suatu wadah pengetahuan yang terorganisasi, menumbuhkan kemampuan untuk menikmati pengalaman imajinatif, membantu perkembangan kecakapan bahasa dan daya pikir, mendidik anak agar dapat menggunakan dan memelihara bahan pustaka secara efsien serta memberikan dasar ke arah studi mandiri.

Penyelenggaraan perpustakaan sekolah bukan hanya untuk mengumpulkan dan menyimpan bahan-bahan pustaka, tetapi dengan adanya penyelenggaraan perpustakaan sekolah diharapkan dapat membantu murid-murid dan guru menyelesaikan tugas-tugas dalam proses belajar mengajar. Oleh sebab itu, segala bahan pustaka yang dimiliki perpustakaan sekolah harus dapat menunjang proses belajar mengajar.

Perpustakaan sekolah bermanfaat apabila benar-benar memperlancar percakapan tujuan proses belajar mengajar di sekolah. Indikasi manfaat tersebut tidak hanya berupa tingginya prestasi murid-murid, tetapi lebih lebih dari itu murid-murid mampu mencari, menemukan, menyaring dan menilai informasi, mereka terbiasa belajar mandiri, terlatih memiliki rasa tanggung jawab, dan selalu mengikuti perkembangan ilmu pengetahuan, teknologi, dan sebagainya.

Secara terinci manfaat perpustakaan sekolah baik yang diselenggarakan oleh sekolah dasar maupun sekolah menengah yaitu: (a) Perpustakaan sekolah dapat menimbulkan kecintaan murid-murid terhadap pembaca; (b) Perpustakaan sekolah dapat memperkaya pengalaman belajar murid-murid; dan (c) Perpustakaan sekolah dapat menanamkan kebiasaan belajar mandiri yang akhirnya murid-murid mampu belajar mandiri.

\section{Tujuan dan Fungsi Perpustakaan Sekolah}

Perpustakaan sekolah sebagai bagian integral dari sekolah, komponen utama pendidikan di sekolah, diharapkan mampu menunjang terhadap pencapaian tujuan pembelajaran di sekolah. Selaras dengan ini, Andi Prastowo mengemukakan bahwa, tujuan perpustakaan sekolah adalah sebagai antara lain: (a) mendorong dan mempercepat proses penguasaan teknik membaca para siswa; (b) membantu menulis kreatif bagi para siswa; (c) menumbuhkembangkan minat dan kebiasaan membaca; (d) menyediakan berbagai macam 
informasi untuk kepentingan

pelaksanaan kurikulum; (e)

mendorong, menggairahkan semangat membaca dan belajar; (f) memperluas, memperdalam, dan memperkaya pengalaman belajar siswa dengan membaca buku dan koleksi lain; dan (g) memberikan hiburan sehat untuk mengisi waktu senggang melalui kegiatan membaca, khususnya bukubuku dan sumber bacaan lain yang bersifat kreatif (Andi Prastowo, 2012: $50)$.
Suatu perpustakaan dapat berdiri dan melakukan tugas dan fungsinya dengan baik apabila memiliki aspekaspek yang diperlukan untuk penyelenggaraannya. Semua itu merupakan modal utama agar operasionalisasi perpustakaan dapat berjalan lancar. Dengan demikian, perpustakaan sekurang-kurangnya harus memiliki unsur-unsur utama, sebagaimana digambarkan dalam bagan di bawah ini:

\section{Bagan 1. Aspek-aspek Pengembangan Perpustakaan}

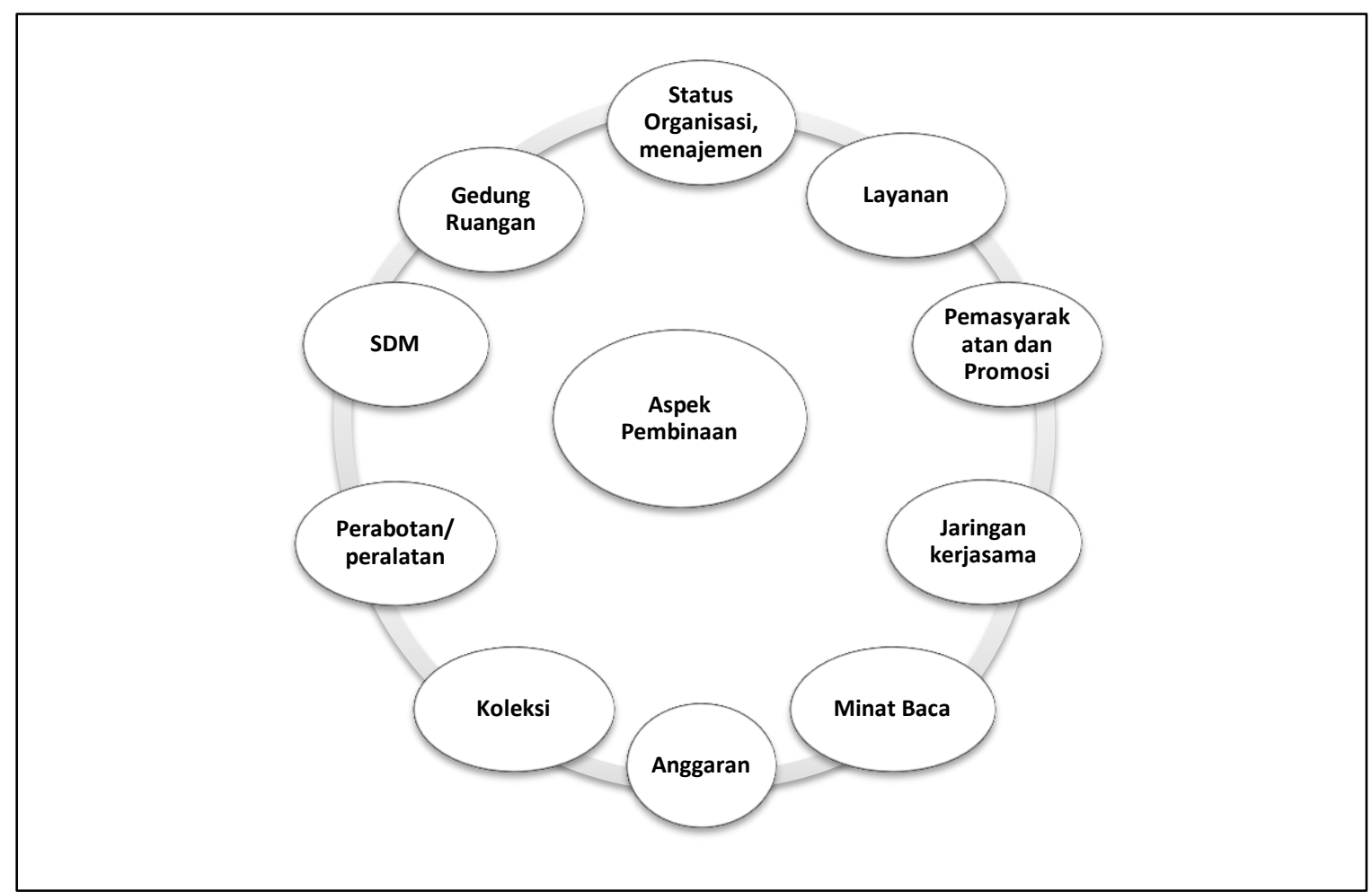

Smith dkk, dalam buku "School library is a center for learning". Ensiklopedinya yang berjudul "The Artinya; perpustakaan sekolah itu merupakan sumber belajar (Bafadal, 
2011: 6). Memang, apabila ditinjau secara umum, perpustakaan sekolah itu sebagai pusat belajar, sebab kegiatan yang paling tampak pada setiap kunjungan murid-murid adalah belajar, baik belajar masalah masalah yang berhubungan lansung dengan mata pelajaran yang diberikan di kelas, maupun buku-buku lain yang tidak ada hubungannya dengan mata pelajaran. Akan tetapi apabila ditinjau dari sudut tujuan untuk belajar, ada yang tujuannya untuk memperoleh informasi, yang ada yang tujuannya untuk berlatih nelusuri buku-buku perpustakaan sekolah, ada yang tujuannya untuk memperoleh informasi, bahkan ada juga murid yang mengunjungi perpustakaan sekolah dengan tujuan hanya sekedar mengisi waktu senggangnya atau sifatnya rekreatif. Berikut ini akan dijelaskan beberapa fungsi perpustakaan sekolah, antara lain:

\section{a. Fungsi Edukatif}

Perpustakaan sekolah menyediakan buku-buku, baik bukubuku fiksi maupun non fiksi. Bukubuku tersebut dapat membiasakan murid-murid belajar mandiri. Perpustakaan sekolah dapat meningkatkan minat baca murid-murid, sehingga teknik membaca semakin lama semakin dikuasai. Selain itu, perpustakaan sekolah menyediakan buku-buku yang disesuaikan dengan kurikulum sekolah. Hal ini dapat menunjang penyelenggaraan pendidikan di sekolah. Perpustakaan sekolah itu memiliki fungsi edukatif (Ibrahim Bafadal, 2011:7)

\section{b. Fungsi Informatif}

Perpustakaan yang sudah maju tidak hanya menyediakan bahanbahan pustaka yang berupa buku saja, tetapi juga menyediakan majalah, bulletin, surat kabar, pamphlet, artikel, peta bahkandilengkapi juga dengan alat-alat pandang dengar, seperti overhead projector, slide projector, film strip projector, televisi, video, tape recorder, dan lain sebagainya. Semua ini akan memberikan informasi yang diperlukan oleh murid-murid. Oleh sebab itu, perpustakaan sekolah memiliki fungsi informatif.

\section{c. Fungsi tanggung jawab administratif}

Fungsi ini tampak pada kegiatan sehari-hari di perpustakaan sekolah. Setiap peminjaman dan pengembalian buku selalu dicatat oleh pustakawan. Setiap murid yang masuk ke perpustakaan harus menunjukkan kartu anggota perpustakaan, tidak diperbolehkan membawa tas, tidak boleh mengganggu teman-temannya 
yang sedang belajar. Apabila ada murid yang terlambat mengembalikan buku pinjamannya didenda, dan apabila ada murid yang telah menghilangkan buku pinjamannya harus menggantinya, baik dengan cara dibelikan di toko, maupun foto kopian. Semua ini mendidik murid-murid bersikap dan bertindak secara administratif (Ibrahim Bafadal, 2011:8).

\section{d. Fungsi Riset}

\section{Perpustakaan menyediakan} banyak bahan pustaka, adanya bahan pustaka yang lengkap, pemustaka dapat melakukan riset, yaitu mengumpulkan data-data yang diperlukan. Misalnya seorang murid ingin meneliti tentang kehidupan orang-orang pada abad ke-17 yang lalu, atau seorang guru ingin meneliti faktor-faktor yang mempengaruhi pertumbuhan tubuh seorang bayi, maka mereka dapat melakukan riset literatur atau yang dikenal dengan sebutan "library research" dengan cara membaca buku-buku yang telah tersedia di dalam perpustakaan (Ibrahim Bafadal, 2011:8).

\section{e. Fungsi rekreatif}

Perpustakaan sekolah dapat berfungsi rekreatif, tidak berarti bahwa secara fisik pergi mengunjungi tempattempat tertentu, tetapi secara psikologis. Sebagai contoh, ada seorang murid yang membaca buku yang berjudul "Malang Kota Indah". Di dalam buku tersebut selain dikemukakan mengenai kota Malang, juga disajikan gambar-gambar, seperti gambar gedung gedung tempattempat hiburan, tempat-tempat para pariwisata, dan sebagainya. Selain itu, fungsi rekreatif berarti bahwa perpustakaan sekolah dapat dijadikan sebagai tempat mengisi waktu luang seperti pada waktu istrahat, dengan cara membaca buku-buku cerita, novel, roman, majalah, surat kabar, dan sebagainya (Ibrahim Bafadal, 2011:8).

\section{Teknologi Informasi di Perpustakaan}

Di era globalisasi, perpustakaan sekolah juga perlu menyesuaikan diri dengan tuntutan masyarakat. Beberapa langkah strategis bisa dilakukan oleh pustakawan untuk mengembangkan perpustakaan sekolah berwawasan global, misalnya dengan perpustakaan sekolah, penerapan aplikasi teknologi informasi (TI) dalam dunia perpustakaan, perpustakaan digital, perpustakaan hybrid, dan pengembangan perpustakaan sekolah dengan paradigma kekinian. Teknologi informasi banyak digunakan untuk 
pengelolaan suatu pekerjaan karena daya efektivitas dan efisiensinya yang sudah terbukti mampu mempercepat kinerja. Kinerja yang cepat dan tepat akan meningkatkan nilai keuntungan bagi suatu lembaga termasuk perpustakaan (Azwar, 2015, 46).

Pemanfaatan teknologi informasi ini dapat memudahkan proses pengelolaan perpustakaan dalam rangka memberikan pelayanan sebaikbaiknya kepada pemustaka. Sistem otomasi, misalnya merupakan salah satu penerapan teknologi informasi, meliputi software dan hardware, di perpustakaan yang dapat memberikan manfaat besar bagi pengelola dalam hal ini pustakawan dan pemustaka atau pengguna (Azwar, 2013: a).

\section{Peran Pustakawan Sekolah}

Sumber daya manusia (SDM) yang unggul dan berkualitas merupakan factor yang sangat penting bagi keberlangsungan lembaga termasuk juga perpustakaan. Apalagi di kondisi saat ini, di mana persaingan bisnis kian menajam sehingga menyadarkan orang bahwa pengetahuan menjadi faktor penting dalam menciptakan keunggulan. Berbagai bidang kegiatan di Indonesia saat ini menghadapi tuntutan untuk melaksanakan manajemen pengetahuan

(knowledge

management) agar tetap eksis.

Konsep manajemen pengetahuan ini meliputi pengelolaan sumber daya manusia (SDM) dan teknologi informasi (TI) dalam rangka untuk mencapai organisasi lembaga yang semakin baik sehingga mampu memenangkan persaingan usaha atau bisnis (Azwar, 2013: 10).

Salah satu komponen
perpustakaan yang memegang
peranan penting adalah pustakawan. Pustakawan sangat diperlukan dalam memberikan pelayanan jasa informasi kepada masyarakat pengguna perpustakaan. Tidak sedikit pengguna perpustakaan yang merasa sangat puas mendapatkan pelayanan perpustakaan.

Pelayanan yang diberikan pustakawan bertingkat sesuai dengan kebutuhan atau keperluan yang dilayani. Peralatan yang digunakan juga bertingkat mulai dari sistem manual sampai dengan digital, setidaknya pustakawan mampu melakukannya dengan profesional.

\section{Kurikulum Tingkat Satuan Pendidikan (KTSP)}

Kurikulum berasal dari bahasa Yunani, curiculum, dan bahasa Prancis cuurier, artinya turun atau 
berlari. Dalam bahasa Inggris, curriculum berarti rencana pelajaran (Echols and Shadily, 1990: 160). Sedangkan dalam bahasa Indonesia, kurikulum berarti perangkat pelajaran yang diajarkan pada lembaga pendidikan (Departemen Pendidikan Nasional, 2008: 617). Istilah kurikulum pada awalnya dipakai dalam dunia olahraga dengan istilah curriculae, yaitu suatu jarak yang harus ditempuh oleh pelari atau kereta dalam perlombaan, dari awal sampai akhir. Dari dunia olahraga istilah kurikulum masuk ke dunia pendidikan yang berarti sejumlah mata kuliah di perguruan tinggi. Dalam kamus Webstar tahun 1955 kurikulum diartikan sejumlah mata pelajaran di sekolah atau mata kuliah di perguruan tinggi yang harus ditempuh untuk mencapai suatu ijazah. Dalam kamus ini kurikulum juga diartikan keseluruhan pelajaran yang disajikan oleh suatu lembaga pendidikan (Nasution, 1982: 7).

Selanjutnya, J.Lioyd Trump dan Delmas F. Miller dalam bukunya Secondary School Improvement (1973), mengartikan kurikulum meliputi metode mengajar dan belajar, cara mengevaluasi murid dan seluruh program, perubahan tenaga mengajar, bimbingan dan penyuluhan, supervise dan administrasi dan hal-hal structural mengenai waktu, jumlah ruangan, serta kemungkinan memilih pelajaran (Kusnandar, 1990: 123).

Berdasarkan beberapa pengertian di atas, dapat di simpulkan bahwa kurikulum adalah seperangkat program atau rencana belajar bagi siswa di bawah tanggung jawab sekolah.

\section{Prinsip Pengembangan KTSP}

Di antara komponen penting dalam pelaksanaan program pendidikan pada semua jenjang pendidikan adalah pengembangan kurikulum. Sebagaimana dikatakan Ginanjar, bahwa pada jenjang pendidikan level bawah dan menengah, setiap satuan pendidikan hendaknya diberikan kewenangan untuk mengembangkan kurikulumnya, tanpa mengurangi isi kurikulum yang berlaku secara nasional (M. Hidayat Ginanjar, 2015: 1022).

Beberapa prinsip dalam pengembangan kurikulum tingkat satuan pendidikan, antara lain: (a) Berpusat pada potensi, perkemba ngan, kebutuhan, dan kepentingan peserta didik dan lingkungannya; (b) Beragam dan terpadu; (c)Tanggap terhadap perkembangan ilmu pengetahuan, teknologi dan seni; (d) 
Relevan dengan kebutuhan

kehidupan; (e) Menyeluruh dan berkesinambungan; (f) Belajar sepanjang hayat; dan (g). Seimbang antara kepentingan nasional dan kepentingan daerah. (Badan Nasional Standar Pendidikan, 2006: 3).

\section{Acuan Operasional Penyusunan Kurikulum Tingkat Satuan Pendidikan}

Beberapa acuan operasional dalam menyusun kKTSP:

a. Peningkatan iman dan takwa serta akhlak mulia.

b. Peningkatan potensi, kecerdasan, dan minat sesuai dengan tingkat perkembangan dan kemampuan peserta didik.

c. Keragaman potensi dan karakteristik daerah dan lingkungan.

d. Tuntutan pembangunan daerah dan nasional.

e. Tuntutan dunia kerja.

f. Perkembangan ilmu pengetahuan, teknologi, dan seni.

g. Agama.

h. Dinamika perkembangan global.

i. Persatuan nasional dan nilainilai kebangsaan.

j. Kondisi sosial budaya masyarakat setempat. k. Kesetaraan jender.

I. Karakteristik satuan pendidikan (Badan Nasional Standar Pendidikan 2006, 8).

\section{Komponen KTSP 2013}

Komponen dari KTSP adalah mencakup, antara lain:

a. Tujuan KTSP

Adapun tujuan dari KTSP adalah:

1) Tujuan pendidikan dasar adalah meletakkan dasar kecerdasan, pengetahuan, kepribadian, akhlak mulia, serta keterampilan untuk hidup mandiri dan mengikuti pendidikan lebih lanjut.

2) Tujuan pendidikan menengah adalah meningkatkan kecerdasan, pe ngetahuan, kepribadian, akhlak mulia, serta keterampilan untuk hidup mandiri dan mengikuti pendidikan lebih lanjut.

3) Tujuan pendidikan menengah kejuruan adalah meningkatkan kecerdasan, pengetahuan, kepribadian, akhlak mulia, serta keterampilan untuk hidup mandiri dan mengikuti pendidikan lebih lanjut sesuai dengan kejuruannya.

b. Struktur dan Muatan KTSP 
Struktur dan muatan KTSP pada jenjang pendidikan dasar dan menengah yang tertuang dalam Standar Isi meliputi lima kelompok mata pelajaran sebagai berikut:

1) Kelompok mata pelajaran agama dan akhlak mulia.

2) Kelompok mata pelajaran kewarganegaraan dan kepribadian.

3) Kelompok mata pelajaran ilmu pengetahuan dan teknologi.

4) Kelompok mata pelajaran estetika.

5) Kelompok mata pelajaran jasmani, olahraga dan kesehatan.

Kelompok mata pelajaran tersebut dilaksanakan melalui muatan dan/atau kegiatan pembelajaran sebagaimana diuraikan dalam PP Nomor 19 Tahun 2005 Pasal 7. Muatan KTSP meliputi sejumlah mata pelajaran yang keluasan dan kedalamannya merupakan beban belajar bagi peserta didik pada satuan pendidikan. Di samping itu, materi muatan lokal dan kegiatan pengembangan diri termasuk ke dalam isi kurikulum.

\section{c. Kalender Pendidikan}

Satuan pendidikan dasar dan menengah dapat menyusun kalender pendidikan sesuai dengan kebutuhan daerah, karakteristik sekolah, kebutuhan peserta didik dan masyarakat dengan memperhatikan kalender pendidikan sebagaimana yang dimuat dalam Standar Isi.

d. Pengembangan silabus

Silabus adalah rencana pembelajaran pada suatu dan/atau kelompok mata pelajaran/tema tertentu yang mencakup standar kompetensi, kompetensi dasar, materi pokok/pembelajaran, kegiatan pembelajaran, indikator, penilaian, alokasi waktu, dan sumber/bahan/alat belajar. Silabus merupakan penjabaran standar kompetensi dan kompetensi dasar ke dalam materi pokok/pembelajaran, kegiatan pembelajaran, dan indikator pencapaian kompetensi untuk penilaian (Badan Standar Nasional Pendidikan 2006, 10).

Kegiatan belajar mengajar yang memotivasi siswa tentunya akan mengaktifkan pembelajaran siswa baik secara jasmaniah maupun secara mental, sehingga siswa terbaik ke dalam golongan siswa yang mempunyai semangat belajar untuk meraih ilmu pengetahuan dan teknologi. Oleh karena itu, guru selaku pendidik dalam lingkungan sekolah tentunya mempersiapkan strategi dalam kegiatan belajar mengajar dalam pencapain kurikulum tingkat 
satuan pendidikan seperti yang dikemukakan (Ajisaka, 2013:21).

KTSP dalam lembaga pendidikan sangat penting karena dapat menggerakkan siswa agar aktif belajar dan terlibat secara terpadu dan berkesinambungan, seperti dikemukakan oleh Kusnandar (1990:22) di antaranya sebagai berikut:

1. Mengarah kepada jenis interaksi belajar mengajar secara optimal.

2. Menuntut berbagai jenis aktivitas belajar siswa dengan mengutamakan aktivitas mental.

3. Strategi belajar mengajar yang sesuai dengan tujuan yang akan dicapai.

4. Multi metode sesuai dengan efek instruksional dan efek pengiring yang akan dicapai.

5. Diarahkan kepada multi sumber belajar relevan, mutakhir, dam tepat guna sesuai dengan bidang studi, lebih khusus lagi topik yang sedang dipelajari

6. Menuntut perubahan kebiasaan cara mengajar dan cara belajar siswa.

Dalam kegiatan belajar-mengajar guru berupaya dengan seoptimal mungkin membimbing, mendidik, dan mengarahkan siswa terhadap sikap dan tingkah laku (fisik), mengembangkan potensi dengan berfikir secara sistematis dan mendalam (mental) untuk menemukan ilmu pengetahuan. Jadi, keterlibatan mental siswa merupakan nilai tambah yang positif terhadap belajar yang aktif, yaitu dengan berusaha untuk menyelesaikan berbagai masalah sendiri, kelompok serta mampu menganalisis berbagai informasi yang diberikan secara searah dengan materi yang diberikan. Dengan demikian, cara belajar siswa aktif dalam kegiatan proses belajar mengajar seoptimal mungkin dalam membimbing, mendidik, dan mengarahkan serta membawa siswa berprestasi dan berkualitas.

\section{METODE PENELITIAN}

Dalam penelitian ini, jenis penelitian yang digunakan adalah jenis penelitian deskriptif (descriptive research) dengan pendekatan analisis data kualitatif purposif sehingga data yang diperoleh dari sumber data (informan) dapat digambarkan secara deskriptif hingga data tersebut sampai ke titik jenuh.

Tujuan dari penelitian dengan jenis deskiptif adalah untuk memberikan 
deskripsi atau gambaran secara sistematis, faktual, dan akurat mengenai fakta-fakta dan sifat-sifat hubungan antar fenomena yang sedang diteliti. Metode kualitatif adalah metode yang dimaksudkan untuk memahami fenomena tentang apa yang dialami oleh subjek penelitian secara holistik dengan cara mendeskripsikan dalam format katakata dan bahasa, pada suatu konteks khusus yang alamiah dengan memanfaatkan berbagai metode alamiah (Lexy J. Moleong, 2004:3).

Penelitian

ini

akan

menggarangkan

peranan

perpustakaan dalam mendukung Kurikulum 2013 di SMK Wiradikarya Ciseeng Kabupaten Bogor. Sedangkan objek penelitian ini bertempat di SMK Wiradikarya Jalan Raya Karihkil, Kecamatan Ciseeng Kabupaten Bogor. Penelitian ini berlangsung selama kurang lebih 5 bulan, dari 1 Agustus hingga 30 Desember 2018.

Informan pada penelitian ini adalah semua pihak yang terlibat dalam pengelolaan perpustakaan SMK Wiradikarya Ciseeng Kabupaten Bogor, terutama kepala sekolah dan staf bagian sarana prasarana, pustakawan, dan tenaga teknis perpustakaan. Dalam penelitian ini penulis menggunakan tiga macam teknik dalam pengumpulan data, yaitu observasi, interview, dan dokumentasi.

\section{HASIL PENELITIAN DAN PEMBAHASAN}

1. Pengelolaan Perpustakaan dalam mendukung Kurikulum 2013 di SMK Wiradikarya Ciseeng Kabupaten Bogor

Perpustakaan sebagai media pembelajaran tidak lepas dari kepentingan untuk mendukung peningkatan kualitas belajar pada peserta didik. Karena itu, perpustakaan sekolah pada lembaga lembaga pendidikan tingkat menengah atas juga merupakan bagian integral dari sekolah sebagai pusat sumber belajar mengajar untuk mendukung tercapainya tujuan pendidikan sekolah. Berdasarkan observasi dan wawancara dengan informan, pengelolaan perpustakaan di SMK Wiradikarya Ciseeng Bogor diarahkan kepada proses pengembangan dan pendalaman materi pelajaran wajib yang dipelajari di sekolah. Koleksi buku yang ada lebih diprioritaskan pada penyediaan bahan pelajaran yang diperlukan oleh siswa. Hal ini dimaksudkan guna mempersiapkan peserta didik dapat memahami adanya transformasi dari KTSP kepada 
pemberlakuan Kurikulum 2013 (W.P.PW.KS-SMK-WD-15-10-2018).

Temuan di atas, selaras dengan pendapat Hartono yang mengatakan bahwa sekolah memiliki paling sedikit 2.500 judul materi perpustakaan yang relevan dan mutakhir serta paling sedikit $60 \%$ koleksi perpustakaan terdiri atas buku nonfiksi yang berkaitan dengan kurikulum (Hartono, 2016: 36).

Kurikulum KTSP dan Kurikulum 2013 memberikan kebijakan desentralisasi pada setiap satuan pendidikan. Penerapan KTSP dalam penyelenggaraan pendidikan di setiap satuan pendidikan diharapkan dapat lebih berkompetisi secara sehat dengan mengacu pada tujuan satuan pendidikan, potensi masyarakat di sekitarnya, dan karakteristik peserta didik sesuai dengan standar nasional pendidikan.

Penerapan

kurikulum sangat membutuhkan sumber belajar terutama perpustakaan. Perpustakaan harus dapat menyesuaikan pada kurikulum baik kegiatan perpustakaan maupun koleksi bahan pustakaan agar dapat memenuhi kebutuhan sivitas sekolah. Maka dari itu, pustakawan harus mengetahui bagaimana penyelanggaraan perpustakaan agar sesuai dengan kurikulum yang digunakan sekolah, yaitu transformasi Kurikulum KTSP kepada Kurikulum 2013 dengan cara memahami karakterisktiknya dengan baik.

\section{a. Peran Perpustakaan}

Perpustakaan mempunyai pengaruh positif yaitu dengan adanya peserta didik yang masuk di perpustakaan untuk mengisi waktu kosongnya untuk ke perpustakaan pada saat guru bidang studi yang bersangkutan tidak masuk. Selain membaca, mereka juga menjadikan perpustakaan sebagai tempat untuk berkumpul sekaligus menyelesaikan tugas-tugas dari gurunya.

\section{b. Ruangan Perpustakaan}

Ruang perpustakaan menjadi sarana yang penting dalam penyelenggaraan perpustakaan karena dalam ruang ini segala aktivitas dan program perpustakaan dirancang dan diselenggarakan dengan baik. Perpustakaan SMK Wiradikarya Ciseeng Kabupaten Bogor menempati area ruangan berukuran $6 \times 4$ meter dengan luas $24 \mathrm{~m}^{2}$ diposisikan satu ruangan dengan ruang praktik siswa SMK menjadikan ruang perpustakaan mudah dijangkau oleh peserta didik di lingkungan sekolah (W.P-PW-KSSMK-WK-30-12-2018). Ruangan perpustakaan yang tidak terlalu luas ini 
terbantu oleh lokasinya yang berada tepat didepan aula asrama yang sangat luas dan kondusif untuk peserta didik membaca atau mengkaji bahan pustaka.

\section{c. Koleksi Perpustakaan}

Koleksi perpustakaan sekolah merupakan sejumlah bahan atau sumber-sumber informasi, baik berupa buku ataupun bukan (non) buku, yang dikelola untuk kepentingan proses belajar mengajar di sekolah yang bersangkutan. Koleksi merupakan senjata dari perpustakaan sekolah. Tanpa adanya koleksi yang memadai, maka perpustakaan SMK Wiradikarya Ciseeng Kabupaten Bogor tidak dapat menjalankan fungsinya secara maksimal. Oleh karena itu, pengelola perpustakaan sekolah wajib mengetahui berbagai jenis koleksi perpustakaan sekolah dan bagaimana pengembangannya agar koleksi tersebut dapat dimanfaatkan secara maksimal oleh para penggunanya. Jenis koleksi perpustakaan SMK Wiradikarya Ciseeng Kabupaten Bogor terdiri dari bahan buku dan bahan non buku. Bahan buku sangat didominasi dengan buku-buku teks atau bukubuku pelajaran. Adapun buku lain berupa ilmu pengetahuan umum lebih banyak berupa buku pengetahuan
Islam dan pengembangan diri (W.PPW-KS-SMK-WK-30-12-2018).

\section{d. Fasilitas Perpustakaan}

Perpustakaan sekolah perlu dirancang dan dibangun senyaman mungkin, seperti halnya ruang tamu di rumah kita. Dalam menyusun perpustakaan SMK Wiradikarya Ciseeng Kabupaten Bogor harus mengakomodasi program-program yang dibutuhkan termasuk koleksi, staff, siswa (OSIS), dan kebutuhan kelas. Yang dimaksud koleksi disini adalah koleksi yang seperti apa yang dibutuhkan siswa, sehingga koleksi di perpustakaan sekolah benar-benar bermanfaat. Staff di sini ialah dibutuhkan berapa staff dalam melakukan kinerja atau programprogram perpustakaan sekolah tersebut. Yang dimaksud kebutuhan kelas adalah perlengkapan apa saja dan fasilitas apa saja yang dibutuhkan kelas, serta tata letaknya yang dapat dirancang sedemikian rupa, sehingga membuat nyaman suasana kelas. Semua hal itu harus dipikirkan secara matang agar perpustakaan sekolah benar-benar dimanfaatkan oleh siswa, guru, maupun yang lainnya.

Dalam merancang perpustakaan sekolah, pustakawan juga harus mampu membangun suasana hati yang baik terhadap siswa maupun 
pengunjung. Sebagian besar perpustakaan sekolah marancang perpustakaan dengan menggabungkan unsur keras dan lunak. Unsur-unsur keras seperti kursi, meja, rak buku, meja computer. Serta unsur lunak seperti karpet, tanaman, tirai, dan sebagainya.

\section{Kendala Perpustakaan dalam Mendukung Kurikulum Tingkat Satuan Pendidikan dan Kurtilas di SMK Wiradikarya Ciseeng Kabupaten Bogor}

Suatu perpustakaan akan mampu menjalankan tugas dan fungsinya dengan baik, apabila semua sistem dan kebutuhan terpenuhi. Namun sejalan dengan apa yang penulis temukan pada perpustakaan SMK Wiradikarya Ciseeng Kabupaten Bogor, mengalami beberapa kendala, antara lain sebagai berikut:

\section{a. Sumber Daya Manusia}

Sumber daya manusia yang mengelola perpustakaan SMK Wiradikarya terdiri dari pustakawan yang merangkap sebagai guru honorer, dibantu dengan tenaga fungsional lain untuk menggerakkan aktivitas perpustakaan. Kualitas mereka perlu ditingkatkan terus menerus agar mampu mengoptimalkan kinerja dan menggerakkan sumber daya lainnya (W.P.KS-SMK-WD-29-12-2018).
Perlunya peningkatan kualitas karena adanya realitas di lapangan bahwa mereka itu kurang motivasi, rendah kinerja, kurang berani tampil, mandul pemikiran dan bekerja statis. Hal-hal seperti inilah yang kurang mampu mendorong perkembangan perpustakaan dan profesi pustakawan di negeri ini. Peningkatan sumber daya manusia tidak harus dengan biaya mahal. Maka upaya peningkatan ini dapat dilaksanakan melalui pendidikan formal, informal dan nonformal. Faktor utama dalam mengelola sebuah perpustakaan harus membutuhkan tenaga yang maksimal sehingga dengan mudah dapat menyelesaikan segala jenis aktivitas dalam suatu perpustakaan, sehingga semuanya dapat berjalan dengan efektif dan efisien. Perpustakaan SMK Wiradikarya Ciseeng Kabupaten Bogor saat ini belum memiliki pustakawan yang ahli dalam bidangnya. Kendala ini membuat manajemen perpustakaan masih sangat terbatas dalam pengembangannya. Hal ini nampak dari kurang terkelolanya perpustakaan yang sebenarnya merupakan jantungnya sebuah lembaga pendidikan formal (W.P-PW-KS-SMKWK-30-12-2018). 
b. Sarana dan Prasarana

Penyediaan sarana dan prasarana di perpustakaan SMK Wiradikarya Ciseeng Kabupaten Bogor merupakan hal yang penting karena dapat menunjang kelancaran kegiatan perpustakaan secara optimal sehingga tugas dan fungsi perpustakaan SMK Wiradikarya Ciseeng Kabupaten Bogor dapat terlaksana. Sarana dan prasarana ini dapat dibedakan menjadi dua yaitu sarana dan prasarana fisik dan sarana dan prasarana non fisik.

Di SMK Wiradikarya Ciseeng Kabupaten Bogor, sarana dan prasarana perpustakaan masih sangat minim dan apa adanya. Hal ini merupakan imbas dari belum adanya pustakawan yang konsen terhadap manjemen perpustakaan sekolah tersebut. Dengan kata lain, sebuah perpustakaan harus menyediakan peralatan dan perlengkapan yang sesuai dengan kondisi ruangan dan tujuan yang ingin dicapainya (W.PPW-KS-SMK-WK-30-12-2018).

\section{c. Dana}

Hampir semua pihak menyetujui mengenai pentingnya keberadaan perpustakaan sekolah dalam menunjang mutu pendidikan di suatu sekolah. Keberadaannya dianggap akan sangat membantu siswa, sekurangnya dalam hal meningkatkan minat baca dan menyediakan koleksi bahan bacaan bagi keperluan tugas belajar. Bagi guru, keberadaan perpustakaan sekolah akan sangat membantu tugasnya dalam proses kegiatan belajar mengajar (KBM) sebagai bagian dari sarana belajar di sekolah. Namun, keberadaan perpustakaan sekolah di SMK Wiradikarya Ciseeng Kabupaten Bogor dinilai minim anggaran dana yang disisipkan untuk penyediaan alat dan pengembangan perpustakaan. Belum adanya program aplikasi khusus untuk pengembangan jaringan (net work) perpustakaan secara lebih luas (W.PPW-KS-SMK-WK-30-12-2018).

\section{E. KESIMPULAN}

Berdasarkan hasil penelitian tentang, pengelolaan perpustakaan di SMK Wiradikarya Ciseeng Bogor cukup mendukung dalam merealisasikan Kurikulum 2013 (Kurtilas) khususnya dalam mencapai tujuan pembelajaran di sekolah. Selain itu, pengelolaan sarana perpustakaan saat ini lebiih diprioritaskan pada penyediaan koleksi bahan pustaka, penyediaan dan penataan ruang baca bagi pengunjung dan adanya penataan koleksi buku dengan baik 
serta adanya tenaga pustakawan yang ahli dalam bidangnya.

Perpustakaan sekolah dapat meningkatkan proses pembelajaran secara berkesinambungan, hal ini terjadi karena kebutuhan akan referensi mata pelajaran untuk semua siswa telah disiapkan oleh perpustakaan.

Kendala yang dihadapi perpustakaan SMK Wiradikarya dalam mendukung realisasi kurikulum 2013 diantaranya; sumber daya manusia, sarana dan prasarana serta keterbatasan dana. Berdasarkan hasil penelitian di atas, disarankan kepada pengelola sekolah agar pengelolaan perpustakaan dapat memberikan kenyamanan dalam ruangan perpustakaan. Perpustakaan juga diharapkan dapat menambah sarana dan prasarananya, agar ke depannya pengelolaannya lebih dan profesional, baik dalam hal penataan, jumlah koleksi dan pengelolaannya serta dapat menambah tenaga pustakawan sesuai keahliannya.

\section{DAFTAR PUSTAKA}

Ajisaka. (2013). Prinsip-Prinsip Dasar Pengembangan Kurikulum Tingkat Satuan Pendidikan (KTSP). Bandung: PT Remaja Rosdakarya.
Atmodiwirio, S. (2005). Manajemen Pendidikan Indonesia. Jakarta: Ardadizya Jaya.

Azwar, M. (2013). Membangun Sistem Otomasi Perpustakaan dengan Senayan.

Badan Nasional Standar Pendidikan. (2006). Penyusun KTSP Kabupaten/Kota: Panduan Penyusunan Kurikulum Tingkat Satuan Pendidikan Jenjang Pendidikan Dasar dan Menengah. Jakarta: Departemen Pendidikan Nasional.

Bafadal, I. (2011). Pengelolaan Perpustakaan Sekolah. Jakarta: PT Bumi Aksara.

Departemen Pendidikan Nasional. (2008). Kamus Besar Bahasa Indonesia. Jakarta: Gramedia.

Ginanjar, M.H. (2012). Reformasi Pendidikan dan Strategi Pembaharuan Sistem Pendidikan Nasional di Era Global. Edukasi Islami: Jurnal Pendidikan Islam, 1(01).

Ginanjar, M.H. (2015). Tantangan dan Peluang Lembaga Pendidikan Islam di Era Masyarakat Ekonomi Asean (MEA). Edukasi Islami: Jurnal Pendidikan Islam, 4(08).

Hartono. (2016). Manajemen Perpustakaan Sekolah Menuju Perpustakaan Modern dan Profesional. Yogyakarta: ArRuzzMedia.

Martoatmojo, K. (2009). Pelayanan Bahan Pustaka. Jakarta: Universitas Terbuka.

Prastowo, A. (2012). Manajemen Perpustakaan Sekolah Profesional. Yogyakarta: Diva Press.

Undang-Undang Republik Indonesia Nomor 20 Tahun 2003 tentang Sistem Pendidikan Nasional. 